\title{
Electrochemical Non-Enzymatic Detection of Glucose Based on 3D Electroformed Copper on $\mathrm{Ni}$ Foam Nanostructures
}

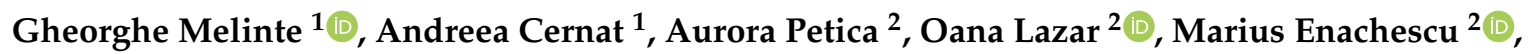 \\ Liana Anicai ${ }^{2}$ (D) and Cecilia Cristea $1, * \mathbb{D}$ \\ 1 Analytical Chemistry Department, Faculty of Pharmacy, Iuliu Haţieganu University of Medicine and \\ Pharmacy, 4 Louis Pasteur St., 400349 Cluj-Napoca, Romania; Melinte.Gheorghe@umfcluj.ro (G.M.); \\ Ilioaia.Andreea@umfcluj.ro (A.C.) \\ 2 Center for Surface Science and Nanotechnology, University Polytechnica of Bucharest, Splaiul Independentei \\ 313, 060042 Bucharest, Romania; aurora.petica@cssnt-upb.ro (A.P.); oana.lazar@cssnt-upb.ro (O.L.); \\ marius.enachescu@cssnt-upb.ro (M.E.); lanicai@itcnet.ro (L.A.) \\ * Correspondence: ccristea@umfcluj.ro
}

Received: 9 May 2020; Accepted: 15 June 2020; Published: 17 June 2020

\begin{abstract}
Despite the fact that the electrochemical biosensors based on glucose oxidase represent the golden standard for the management of diabetes, the elaboration of nonenzymatic sensors became extensively studied as an out-of-the-box concept that aims to simplify the existing approach. An important point of view is represented by the low price of the sensing device that has positive effects for both end-users and healthcare systems. The enzyme-free sensors based on low-cost materials such as transition metals have similar analytical properties to the commercial ones while eliminating the issues associated with the presence of the enzyme, such as the stability issues and limited shelf-life. The development of nanoporous nanomaterials for biomedical applications and electrocatalysis was referred to as an alternative to the conventional methods due to their enlarged area, electrical properties, ease of functionalization and not least to their low cost. Herein, we report the development of an electrochemical nonenzymatic sensor for glucose based on 3D copper nanostructures with $\mathrm{Ni}$ foams as promotor of the enhanced nanoporous morphology. The sensors were successfully tested in the presence of the designated target, even in the presence of common interference agents found in biological samples.
\end{abstract}

Keywords: glucose; modified electrodes; non-enzymatic detection; 3D electroformed $\mathrm{Cu}$; electrochemical detection

\section{Introduction}

The World Health Organization recently reported more than 422 million people suffering from diabetes, especially in developing and poor countries [1]. Diabetes is a serious chronic disease that occurs in two cases: the pancreas is not able to produce enough insulin or the body cannot effectively use the insulin it produces [1].

Diabetes of all types is a serious health issue leading to complications and with an increased overall risk of dying prematurely. The most reported complications include heart attack, stroke, kidney failure, leg amputation, vision loss and nerve damage. Poorly controlled diabetes also increases the risk of fetal death and other complications during pregnancy. A successful approach of living well with diabetes is an early diagnosis, meaning that the longer a person lives with undiagnosed and untreated diabetes, the worse their health outcomes are likely to be. A very useful and affordable method that should be available in primary healthcare settings is the access to basic diagnostics, such as blood 
glucose (denoted Glu) testing. In this case, validated systems for referral and back-referral are needed, as patients will need periodic specialist assessment or treatment for complications. For patients with diabetes, several cost-effective interventions can improve their outcomes, irrespective of what type of diabetes they may have. These interventions include Glu exact control, through a combination of factors like diet, physical activity and, if necessary, medication; control of blood pressure and the amount of lipids in order to reduce the cardiovascular risk and other complications; and regular screening for damage to the eyes, kidneys and feet aiming to facilitate early treatment. For diabetes management the use of standards and protocols is highly recommended and most important $[1,2]$. Therefore, a continuous monitoring of the body Glu level is required in order to reduce the mortality rate and to maintain the physical body characteristics. Blood sugar monitoring devices are commonly and currently used to properly manage diabetes.

A large range of techniques are involved to measure the Glu concentration, including optical [3], coulometric [4], capacitive detection [5], spectrophotometry, high-performance liquid chromatography, Raman, infrared spectroscopy (IR), electronic, fluorescent, acoustic and transdermal ones [6-8].

Currently, most Glu biosensors are of the electrochemical type due to their enhanced sensitivity, reproducibility, simplicity of use, easy maintenance and lower cost [2,6,9]. Most of the commercially available Glu biosensors are based on the use of enzyme-based electrochemical detection involving amperometric methodology, and they have been widely investigated over the last few decades [6,9]. All types of enzyme-based biosensors require laborious and complex enzyme immobilization procedures which induce an uncertainty related to the artificially engineered biological substances, regardless of the type of the enzymes. Therefore, in spite of their high Glu selectivity, they suffer from reproducibility, instability, deactivation due to long time storage and exposure to elevated temperatures, as well as from a relatively higher cost [9-11]. Under these circumstances, the development of non-enzymatic electrochemical sensors without biological functional units has attracted an increased interest thanks to their structural simplicity, lower cost and better quality control for mass production, while benefitting from the current development of a large range of novel nanostructured materials possessing various morphologies [9,11-14]

The rapid advancement in nanoscience and nanotechnology has opened new approaches for the preparation of nanostructured electrodes either as films or as nanoparticles, nanowires, nanorods or nanotubes, which are usually characterized by electrocatalytic properties due to the enlargement of surface area, generation of electrocatalytic active sites and formation of nano-space enclosed by conducting surfaces $[2,9,11,15-21]$.

Single and binary noble metal nanomaterials as well as their hybrid with carbon-based nanomaterials have been widely studied to build electrodes for non-enzymatic Glu detection, including Pt [22-25] Au [26-28], Pt-Au nanocorals [29], Pt-Pd nanoflakes [30] and nanoporous PtAg [31]. Although noble metals show high sensitivity towards Glu oxidation, the surface poisoning due to the adsorption of intermediates and chloride ions remains a challenge. In addition, a major drawback is their high cost, which makes them less competitive in practical applications.

There has been a growing interest in the fabrication of non-enzymatic glucose Glu sensors based on cheaper non-precious transition metals [9,32]. Particularly, Ni-, $\mathrm{Cu}$ - and Co-based metal and metal oxide structures have been studied due to their good catalytic performance $[11,19,21,32,33]$. Various $\mathrm{Cu}, \mathrm{Cu}$ compounds and $\mathrm{Cu}$ alloy nanomaterials possessing different morphologies have been investigated as electrodes for Glu electrochemical detection, including $\mathrm{Cu}$ nanowires $[2,9,16,17]$, $\mathrm{Cu}(\mathrm{OH})_{2}$ nano-flowers [34] or nano-tubes [35], $\mathrm{Cu}_{2} \mathrm{O}$ or CuO-based nanostructures [36,37], as well as $\mathrm{Cu} / \mathrm{Co}$ bilayers [19] and $\mathrm{Cu} / \mathrm{Ni}$ nanostructures [38,39]. Compared to other types of morphologies, i.e., nanowires, nanorods, nanotubes, etc., the development of novel nanoporous materials have also attracted an increased interest for applications in electrocatalysis and electroanalysis. Besides an enlarged specific surface area, they possess other interesting properties such as the nano-confinement effect, electrical layer overlapping discriminative electrokinetics, ion-selective impedance, etc. [40,41]. 
In addition, functionalization of nanoporous materials by applying additional coatings of metals or oxides may also enhance the electrocatalytic or electroanalytical effect [42,43].

Considering everything discussed above, this paper aims to assess a novel sensing platform for the non-enzymatic electrochemical detection of Glu based on 3D electroformed copper nanostructures with enhanced porosity. Therefore, the electrochemical preparation and characterization of 3D Cu nanoporous electrodes were initially presented. The prepared electrodes were then investigated as the main component of the Glu sensor involving chronoamperometry. Their linear range, detection limit and selectivity are determined and discussed.

\section{Materials and Methods}

\subsection{Reagents and Instruments}

Nickel chloride $\left(\mathrm{NiCl}_{2} \cdot 6 \mathrm{H}_{2} \mathrm{O}\right)$, copper sulfate $\left(\mathrm{CuSO}_{4} \cdot 5 \mathrm{H}_{2} \mathrm{O}\right)$, ammonium chloride $\left(\mathrm{NH}_{4} \mathrm{Cl}\right)$, sulfuric acid $\left(\mathrm{H}_{2} \mathrm{SO}_{4}\right)$, nitric acid $\left(\mathrm{HNO}_{3}\right)$, potassium ferro/ferricyanide $\left(\left[\mathrm{Fe}(\mathrm{CN})_{6}\right]^{3-/ 4-}\right)$, sodium hydroxide $(\mathrm{NaOH}), \mathrm{D}-(+)-\mathrm{Glu}\left(\mathrm{C}_{6} \mathrm{H}_{12} \mathrm{O}_{6}\right)$, paracetamol $(\mathrm{P})$, ascorbic acid (AA), Rhamnose (R) and uric acid (UA) were purchased from Sigma-Aldrich, Darmstad, Germany and used as received. The commercial human serum was purchased also from Sigma-Aldrich and kept at $-20^{\circ} \mathrm{C}$. All reagents were at least of p.a. grade and the solutions were prepared using Milli-Q ultrapure water $(18 \mathrm{M} \Omega / \mathrm{cm})$.

Electrochemical investigations were performed involving PARSTAT 4000 (Princeton Applied Research, AMETEK Scientific Instruments, Oak Ridge, TN, USA) ), Autolab PGSTAT302N (Metrohm, Eco Chemie, The Netherlands) and Palmsens EmStat Blue potentiostats PalmSens BV, GA Houten, The Netherlands), using a three-electrode cell where a platinum wire (BASi, West Lafayette, IN, USA) and a $\mathrm{Ag} / \mathrm{AgCl}$ electrode (BASi, West Lafayette, IN, USA) served as the counter and reference electrode, respectively. $\mathrm{Cu}$ strip and different $\mathrm{Cu}$ nanoporous morphologies acted as working electrodes. The working volume was 5 or $10 \mathrm{~mL}$ solution under continuous stirring using a magnetic stirrer FALC F70, 100-1800rpm (Falc Instruments, Treviglio, Italy).

The morphology and elemental composition of the prepared 3D electroformed copper nanostructures were examined using scanning electron microscopy (SEM), associated with energy dispersive X-ray spectroscopy (EDX) (SU8230, HITACHI High-Technologies Corp., Tokyo, Japan equipped with EDX Oxford detector analyzer, Oxford Instruments NanoAnalysis \& Asylum Research, High Wycombe, UK). The chemical composition and crystal phase of the porous nanostructures were determined using X-ray diffractometry (XRD) (High Resolution SmartLab X-ray diffractometer Rigaku, Tokyo, Japan, $9 \mathrm{~kW}$, with rotating anode,) using CuK radiation, at a speed of $2 \mathrm{~s} / \mathrm{step}\left(1 \mathrm{step}=0.05^{\circ}\right)$.

\subsection{Preparation of the $3 D \mathrm{Cu}$ Nanoporous Electrodes}

The $\mathrm{Cu}$ nanoporous electrodes were electrochemically synthesized onto $\mathrm{Cu}$ metallic strips, initially subjected to surface preparation consisting of mechanical polishing using 1000 and 2000 abrasive paper, followed by chemical pickling in $1: 1 \mathrm{HNO}_{3}: \mathrm{H}_{2} \mathrm{O}$ solution at $25^{\circ} \mathrm{C}$ for $20-30 \mathrm{~s}$, then rinsed with running water and distilled water and air dried.

The selected electrodeposition route to obtain the $\mathrm{Cu}$ nanoporous electrodes consisted of (i) the electrochemical growth of $\mathrm{Ni}$ foams on $\mathrm{Cu}$ involving the dynamic hydrogen bubble template according to [44,45], followed by (ii) $\mathrm{Cu}$ deposition using a classical acidic sulfate type electrolyte. The compositions of the used electrolytes and the operation conditions are summarized in Table 1. 
Table 1. Electrolytes composition and operating conditions for electrochemical preparation of the 3D $\mathrm{Cu}$ nanoporous electrodes.

\begin{tabular}{ccc}
\hline Coating System & Electrolyte Composition & Operating Conditions \\
\hline & & $\mathrm{pH}=4-4.5$ \\
$\mathrm{Cu} / \mathrm{Ni} \mathrm{foam}$ & (i) $0.1 \mathrm{M} \mathrm{NiCl}_{2} \cdot 6 \mathrm{H}_{2} \mathrm{O}+2 \mathrm{M} \mathrm{NH}{ }_{4} \mathrm{Cl}$ & $\mathrm{T}=2{ }^{\circ} \mathrm{C}$ \\
& & $\mathrm{i}=1 \mathrm{~A} / \mathrm{cm}^{2}$ \\
& & time $=3 \mathrm{~min}$. \\
& (ii) $0.8 \mathrm{M} \mathrm{CuSO}_{4} \cdot 5 \mathrm{H}_{2} \mathrm{O}+0.6 \mathrm{M} \mathrm{H}_{2} \mathrm{SO}_{4}$ & $\mathrm{~T}=25-30{ }^{\circ} \mathrm{C}$ \\
& & $\mathrm{i}=28-35 \mathrm{~mA} / \mathrm{cm}^{2}$ \\
& & time $=15-20 \mathrm{~min}$. \\
\hline
\end{tabular}

\subsection{Electrochemical Assessment of 3D Cu Nanoporous Electrodes}

Preliminary experimental investigations involving electrochemical impedance spectroscopy (EIS) in $5 \mathrm{mM}\left[\mathrm{Fe}(\mathrm{CN})_{6}\right]^{3-/ 4-}$ dissolved in $0.1 \mathrm{M} \mathrm{NaOH}$ solution, as redox probe, on a frequency window of $10 \mathrm{mHz}$ to $100 \mathrm{KHz}$ at open circuit potential were performed on $\mathrm{Cu}$ strip and Cu-based nanoporous coating systems having a constant geometrical area of $0.63 \mathrm{~cm}^{2}$, in order to get more information on their electrochemical characteristics. The fitting of the impedance data was performed using ZView 2.4 software from Scribner Association Inc., Derek Johnson (Southern Pines, NC, USA). In addition, cyclic voltammetry $(\mathrm{CV})$ investigations were also done in the same solution, for scan rates between 10 and $50 \mathrm{mV} / \mathrm{s}$.

$\mathrm{CV}$ experiments in $0.1 \mathrm{M} \mathrm{NaOH}$ solution in the absence and in the presence of $0.225 \mathrm{mM}$ Glu were recorded to assess the electrochemical response for this analyte of the investigated $\mathrm{Cu}$ strip and $\mathrm{Cu}$-based nanoporous electrodes. The potential was swept twice from $0 \mathrm{~V}$ to $0.8 \mathrm{~V}$ with a scan rate of $10 \mathrm{mV} / \mathrm{s}$.

The detection of Glu was performed using chronoamperometry (CA) at $+0.55 \mathrm{~V}$ vs. $\mathrm{Ag} / \mathrm{AgCl}$ in $5 \mathrm{~mL} 0.1 \mathrm{M} \mathrm{NaOH}$ solution under continuous stirring at $500 \mathrm{rpm}$ (interval time $0.1 \mathrm{~s}$, analysis time: up to $1200-1600 \mathrm{~s}$ ), with successive additions every $100 \mathrm{~s}$ of $2.5 \mathrm{mM}$ analyte solution (the first 4 additions of $12.5 \mu \mathrm{L}$, followed by $50 \mu \mathrm{L}$ of the standard solution) or $25 \mathrm{mM}$ Glu ( $50 \mu \mathrm{L}$ additions).

The interference experiments were performed using the same protocol in the presence of several electroactive species, respectively: paracetamol (P), ascorbic acid (AA), Rhamnose (R) and uric acid (UA). The additions of the interfering species (a final concentration of $20 \mu \mathrm{M}$ ) were alternated with those of the analyte (a final concentration of $400 \mu \mathrm{M}$ ) to confirm the selectivity of the platform. The experiments were performed on a working surface area of $25 \mathrm{~mm}^{2}$.

The studies on real samples were performed on commercial human serum after a dilution step $1: 100$ with $0.1 \mathrm{M} \mathrm{NaOH}$. CA at $+0.55 \mathrm{~V}$ vs. $\mathrm{Ag} / \mathrm{AgCl}$ was performed in $10 \mathrm{~mL} \mathrm{NaOH}$ with successive additions every $50 \mathrm{~s}$ of $0.1 \mathrm{M}$ Glu in different volumes of $0.1 \mathrm{M} \mathrm{NaOH}(10 \mu \mathrm{L}, 20 \mu \mathrm{L}, 40 \mu \mathrm{L}, 60 \mu \mathrm{L}$, $80 \mu \mathrm{L}$, each volume 4 times). The experiments were performed on a working surface area of $6 \mathrm{~mm}^{2}$.

All electrochemical experiments were conducted at room temperature.

\section{Results and Discussions}

\subsection{Preparation and Characterization of 3D Cu Nanoporous Electrodes}

Electrodeposition of $\mathrm{Ni}$ foams on $\mathrm{Cu}$ substrates involving the chloride type electrolyte having the composition shown in Table 1 facilitated the formation of porous structures with different sizes of the pore's diameter, depending on the applied current density and deposition time. Uniform, dark grey layers were formed, regardless of the applied preparation parameters. A typical morphology of the electrodeposited $\mathrm{Ni}$ foam is illustrated in Figure 1. 


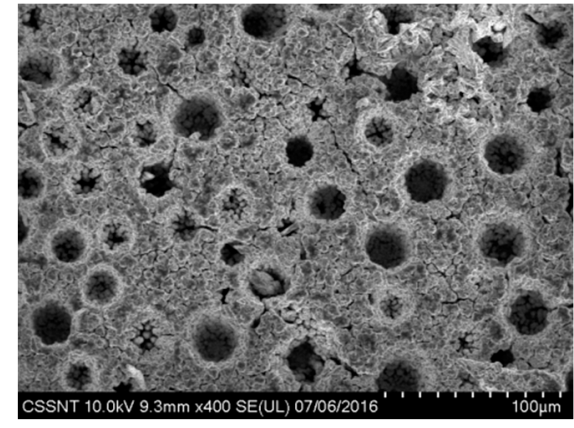

(A)

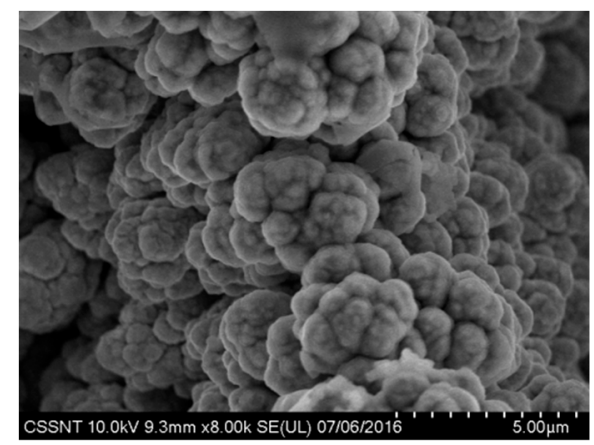

(B)

Figure 1. SEM micrographs at different magnifications for electrodeposited $\mathrm{Ni}_{\mathrm{f}}\left(1 \mathrm{~A} / \mathrm{cm}^{2}, 3 \mathrm{~min}\right.$. $)$ onto Cu metallic substrate. (A) $\times 400,($ B $) \times 8000$.

The development of this type of structure is mainly determined by the hydrogen bubbling occurring simultaneously to the electrochemical reduction of nickel ions, acting as a dynamic template. This type of morphology possesses a large specific surface area facilitating an enhancement of the electrocatalytic or electroanalytical response [37,40,43-45]. As shown in Figure 1, a relatively uniform porous structure may be noticed, presenting both macroporosity (pore diameters of about 25-35 $\mu \mathrm{m}$ ) and microporosity (pore diameters of about $3-5 \mu \mathrm{m}$ ) features. In addition, the deposits show a nodular growth, leading to a cauliflower-like morphology.

In order to get more information on the distribution of the $\mathrm{Ni}$ foam pore diameter sizes, a statistical analysis was performed and the pore diameters were extracted from a low magnification SEM image by measuring around 150 individual pores. The histogram was best fitted with a Gauss function (not shown here), exhibiting a unimodal distribution of pore diameters. The highest number of pores were found to be within a 20 and $45 \mu \mathrm{m}$ diameter size range. The mean diameter size of the pores was calculated as $31.25 \pm 8.4 \mu \mathrm{m}$.

It is well known that the electrochemical deposition is an atomic/molecular-level process so that a deposited layer entirely takes the three-dimensional shape of the substrate with a very high accuracy. Therefore, electrodeposition onto a 3D architecture will keep the substrate profile [44-46]. Moreover, the subsequent electrodeposition of $\mathrm{Cu}$ from the acidic electrolyte combines the strong porous support with the high conductivity and reactivity of $\mathrm{Cu}$.

Figure 2 presents an example of the obtained morphology of $\mathrm{Cu}$ electrodeposited onto Ni foam substrate and the corresponding EDX spectrum. As expected, the porous structure of genuine Ni foam is clearly evidenced. Pores having diameters in the range of 10 to $20 \mu \mathrm{m}$ and an internal structure of the $\mathrm{Cu}$ deposit possessing a globular-like structure with an average diameter of about $100 \mathrm{~nm}$ may be noticed.

The EDX analysis of the $\mathrm{Cu} / \mathrm{N}_{\mathrm{f}}$ electrode in Figure 2 revealed the presence of $\mathrm{Cu}$ and Ni elements besides $\mathrm{O}$, where the atomic content of $\mathrm{Ni}$ was far less than that of $\mathrm{Cu}$, suggesting the $\mathrm{Cu}$ deposit successfully covered the $\mathrm{Ni}_{\mathrm{f}}$ substrate. The chemical composition and crystal phase of the electrodes was examined using XRD analysis, as shown in Figure 3.

The electroformed $\mathrm{Ni}$ foam showed $\mathrm{Ni}$ characteristic peaks at $44^{\circ}, 51^{\circ}, 76^{\circ}, 92^{\circ}$ and $98^{\circ}$, corresponding to the (111), (200), (220), (311), and (222) reflections of the f.c.c. structure [47]. After $\mathrm{Cu}$ electrodeposition onto $\mathrm{Ni}_{\mathrm{f}}$, new diffraction peaks appearing in the XRD pattern can be well indexed to the (111), (200) and (220) crystal planes of the f.c.c. polycrystalline copper standard (PDF card No. 00-004-0836). 


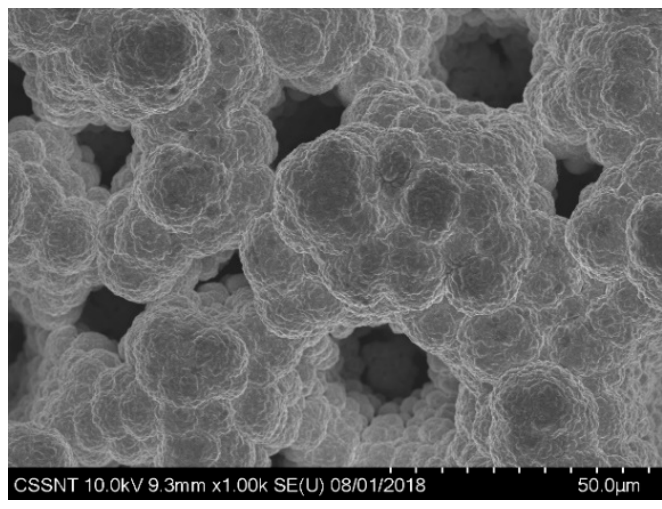

(A)

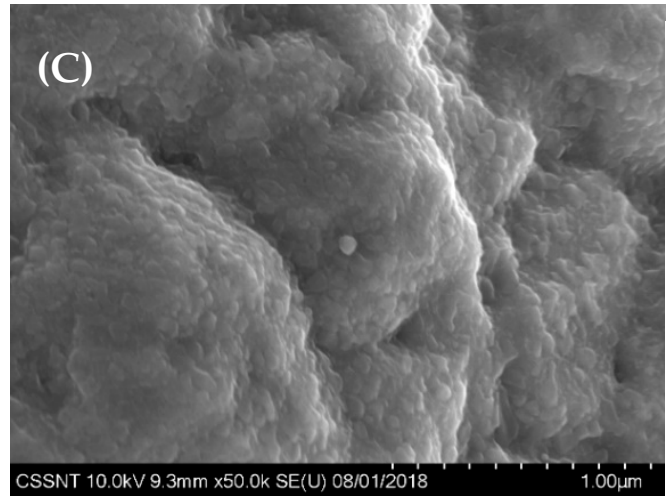

(C)

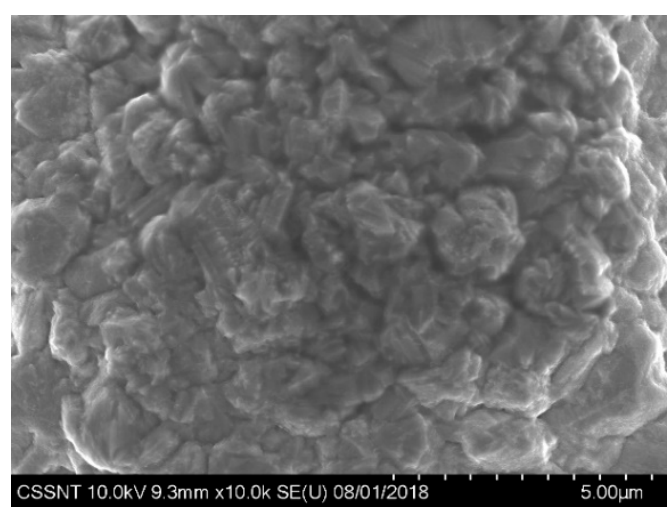

(B)

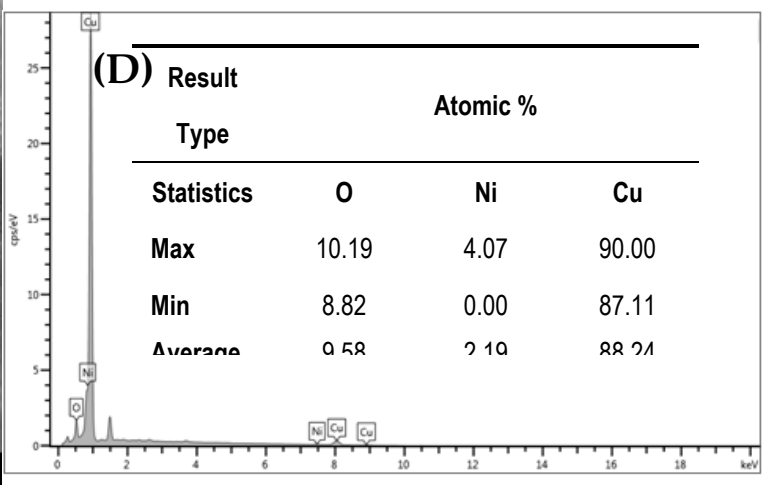

(D)

Figure 2. SEM micrographs at different magnifications $(A: \times 1000 ; \mathbf{B}: \times 10,000 ; \mathbf{C}: \times 50,000)$ and corresponding EDX analysis (D) of Cu electrodeposited onto Ni foam at $35 \mathrm{~mA} / \mathrm{cm}^{2}$ for $15 \mathrm{~min}$.

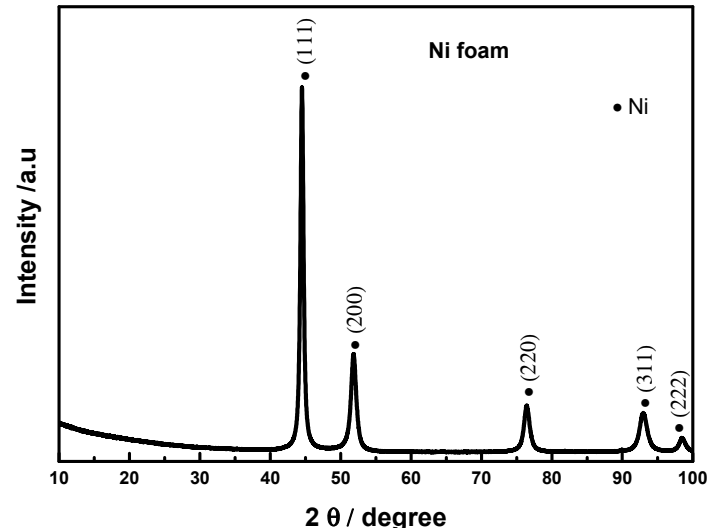

(A)

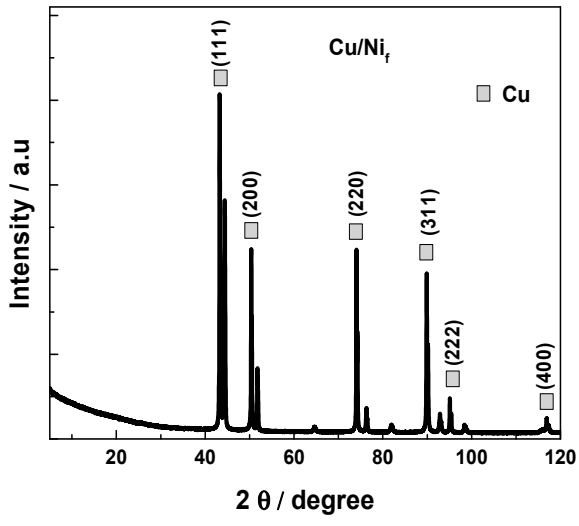

(B)

Figure 3. X-ray diffractograms for electrodeposited $\mathrm{Ni}$ foam at $1 \mathrm{~A} / \mathrm{cm}^{2}$ for $3 \mathrm{~min}$. (A) and for $\mathrm{Cu} / \mathrm{Ni}_{\mathrm{f}}$ electrode (B) (Cu electrodeposited onto $\mathrm{Ni}$ foam at $35 \mathrm{~mA} / \mathrm{cm}^{2}$ for $15 \mathrm{~min}$.).

The resulting $\mathrm{Cu} / \mathrm{Ni}_{\mathrm{f}}$ electrode was then subjected to electrochemical characterization.

\subsection{Electrochemical Characterization of 3D Cu Nanoporous Electrodes}

The interfacial charge-transfer phenomena on the electrodes was investigated involving EIS measurements using an electrolyte consisting of $5 \mathrm{mM}\left[\mathrm{Fe}(\mathrm{CN})_{6}\right]^{3-/ 4-}$ in $0.1 \mathrm{M} \mathrm{NaOH}$, at open circuit potential. Figure 4 comparatively presents the recorded EIS spectra for $\mathrm{Cu}$ strip, $\mathrm{Ni}_{\mathrm{f}}$ and $\mathrm{Cu} / \mathrm{Ni}_{\mathrm{f}}$ electrodes as Nyquist and Bode plots. 


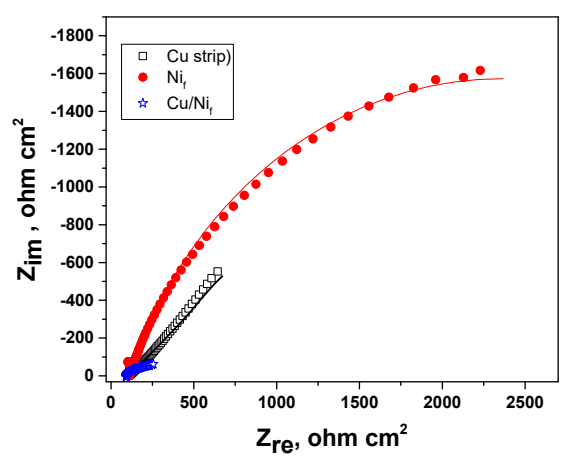

(A)

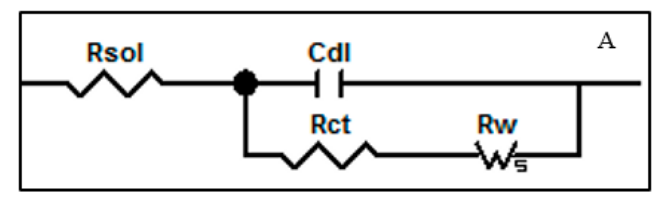

(C)

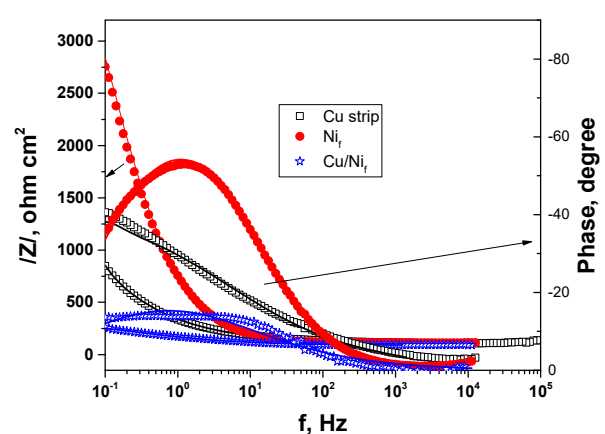

(B)

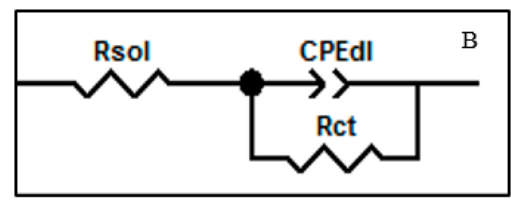

(D)

Figure 4. EIS data recorded in $5 \mathrm{mM}\left[\mathrm{Fe}(\mathrm{CN})_{6}\right]^{3-/ 4-}$ in $0.1 \mathrm{M} \mathrm{NaOH}$ solution for $\mathrm{Cu}$ strip, $\mathrm{Ni}_{\mathrm{f}}$ and $\mathrm{Cu} / \mathrm{Ni}_{\mathrm{f}}$ electrodes as Nyquist (A) and Bode (B) plots. A and B represent the proposed equivalent circuit to fit the measured points. (C and D)

A single very small semicircle followed by a straight line at low frequency is evidenced in the Nyquist plot of the $\mathrm{Cu}$ strip electrode, usually characteristic of diffusive processes, showing the very low charge transfer resistance $\left(R_{c t}\right)$ of the $\mathrm{Fe}(\mathrm{CN})_{6}{ }^{3-/ 4-}$ in slightly alkaline medium in agreement with [48].

The Ni foam electrode exhibits a broadened semicircle, assigned to the porous surface presence. As expected, the $\mathrm{Cu} / \mathrm{Ni}_{\mathrm{f}}$ electrode presents a very low semicircle, suggesting an improvement of the electron transfer rate.

In order to fit the experimental data, simple equivalent circuit models have been used (as shown in Figure 4). In the case of the $\mathrm{Cu}$ strip and $\mathrm{Cu} / \mathrm{Nif}$ electrodes, the equivalent circuit model $\mathrm{A}$ was involved, comprising the solution resistance $\left(R_{s o l}\right)$, in series with a combination between the double-layer capacitance $\left(C P E_{d l}\right)$ in parallel with the charge transfer resistance $\left(R_{c t}\right)$. To take into account the diffusion process that occurs through the metallic layer, a Warburg element $\left(R_{W}\right)$ was added. The fitting of experimental data related to the $\mathrm{Ni}_{\mathrm{f}}$ electrode was performed involving the equivalent circuit model $\mathrm{B}$, consisting of the solution resistance $\left(R_{\text {sol }}\right)$, in series with a combination between a constant phase element corresponding to the double-layer capacitance $\left(C P E_{d l}\right)$ in parallel with the charge transfer resistance $\left(R_{c t}\right)$. During fitting, double-layer capacitances were replaced by a constant phase element $(C P E)$. In general, the use of $C P E$ is appropriate when inhomogeneities are present at atomic or molecular level, including the surface roughness/porosity, diffusion or adsorption [49]. The coefficient $\mathrm{T}\left(\mathrm{F} \mathrm{s}^{\mathrm{n}-1} / \mathrm{cm}^{2}\right)$ was used as capacitive parameter. The selected equivalent circuit showed quite good agreement between the experimental data (symbols) and simulated data (solid lines).

The values of impedance parameters, which are obtained by fitting the impedance data with ZView software using the equivalent circuits proposed in Figure 4, are listed in Table 2.

As can be seen from Figure 4, the value of $R_{c t}$ corresponding to the $\mathrm{Ni}_{\mathrm{f}}$ electrode as substrate significantly decreased as the $\mathrm{Cu}$ layer was deposited, from around $4500 \Omega$ towards $10 \Omega$, suggesting an improvement of the electron transfer rate. Therefore, the presence of the supplementary metallic $\mathrm{Cu}$ on the foam layer improved the electron transfer rate, highlighting the properties of the new electroformed porous material. In addition, the overall resistance including $\mathrm{R}_{\mathrm{W}}$ in the case of the $\mathrm{Cu}$ strip exceeds the value obtained in the case of the $\mathrm{Cu} / \mathrm{Ni}_{\mathrm{f}}$ electrode, showing an improved electron transfer rate, too. 
Table 2. Fitting results of impedance spectra for $\mathrm{Cu}$ strip, $\mathrm{Ni}_{\mathrm{f}}$ and $\mathrm{Cu} / \mathrm{Ni}_{\mathrm{f}}$ electrodes recorded in $5 \mathrm{mM}$ $\left[\mathrm{Fe}(\mathrm{CN})_{6}\right]^{3-/ 4-}$ in $0.1 \mathrm{M} \mathrm{NaOH}$ solution using the equivalent circuits proposed in Figure 4.

\begin{tabular}{cccccc}
\hline $\begin{array}{c}\text { Working Electrode } \\
\text { Type }\end{array}$ & $\mathbf{R}_{\mathbf{s}} / \mathbf{~ o h m ~ \mathbf { ~ m } ^ { 2 }}$ & $\mathbf{R}_{\mathbf{c t}} / \mathbf{o h m ~ \mathbf { ~ m } ^ { 2 }}$ & $\mathbf{C}_{\mathbf{d l}} / \boldsymbol{\mu F}$ & $\mathbf{R}_{\mathbf{W}} / \mathbf{o h m ~ \mathbf { ~ m } ^ { 2 }}$ & The Used Model \\
\hline $\mathbf{C u ~ s t r i p}$ & 80.6 & 20 & 21.5 & 521 & $(\mathrm{~A})$ \\
$\mathbf{N i}$ & 111.2 & 4473 & 210.1 & - & $(\mathrm{B})$ \\
$\mathbf{C u} / \mathbf{N i}_{\mathbf{f}}$ & 185.4 & 10 & 291.5 & 348 & $(\mathrm{~A})$ \\
\hline
\end{tabular}

From the calculated double-layer capacitances, $C_{d l}$, and taking into consideration the average double-layer capacitance of a smooth metal surface of $20 \mu \mathrm{F} / \mathrm{cm}^{2}$ [50], the real surface area $\left(A_{\text {real }}\right)$ may be calculated as

$$
A_{\text {real }}=\frac{C_{d l}}{20}\left[\mathrm{~cm}^{2}\right]
$$

The roughness factor, $\sigma$, which is related to the real to geometrical surface area $\left(A_{\text {geometric }}\right)$ ratio, is calculated as

$$
\sigma=\frac{A_{\text {real }}}{A_{\text {geometric }}}
$$

Table 3 presents the double-layer capacitance, real surface area and corresponding surface roughness values for the investigated electrodes calculated from the EIS data.

Table 3. Double-layer capacitance, real surface area and corresponding surface roughness values for the investigated $\mathrm{Cu}$ electrodes calculated from the EIS data.

\begin{tabular}{cccc}
\hline Working Electrode Type & $\mathrm{CPE}_{\mathrm{dl}} / \mathbf{\mu F}$ & $A_{\text {real }} / \mathrm{cm}^{2}$ & $\boldsymbol{\sigma}$ \\
\hline $\mathrm{Cu} \mathrm{strip}$ & 21.5 & 1.07 & 1.69 \\
$\mathrm{Ni}_{\mathrm{f}}$ & 210.1 & 10.5 & 16.67 \\
$\mathrm{Cu} / \mathrm{Ni}_{\mathrm{f}}$ & 291.5 & 14.5 & 23.1 \\
\hline
\end{tabular}

As expected, the use of the $\mathrm{Ni}$ foam porous substrate facilitated higher roughness values, which may further exhibit a positive influence on the electroanalytical characteristics of the electrode, in agreement also with data reported in [45]. In addition, an increase of the roughness factor was noticed in the case of the $\mathrm{Cu} / \mathrm{Nif}$ electrode, which may be attributed to the $\mathrm{Cu}$ electrodeposition procedure which involved an additive-free electrolyte, thus leading to a slightly more porous surface, in agreement with [51].

In order to get more information on the electrochemical characteristics of the $\mathrm{Cu} / \mathrm{Nif}$ proposed electrode, comparative cyclic voltammetry investigations were performed at various scan rates between 10 and $50 \mathrm{mV} / \mathrm{s}$ involving $5 \mathrm{mM}\left[\mathrm{Fe}(\mathrm{CN})_{6}\right]^{3-/ 4-}$ in $0.1 \mathrm{M} \mathrm{NaOH}$ solution, as exemplified in Figure 5 . Usually, the ferrocyanide/ferricyanide redox couple is used as the model redox couple. This is considered a quasi-reversible couple [52] and is very stable during electrochemical experiments.

As observed, for all three electrodes ( $\mathrm{Cu}$ strip, Nif and $\mathrm{Cu} / \mathrm{Nif})$, the potential of the anodic and cathodic peaks is approximately the same, whatever the chemical nature of the electrode surface. Furthermore, the peak currents for the three electrode materials are quite similar for both electrode processes (anodic and cathodic). However, as expected the corresponding currents of the redox peaks are the highest for the $\mathrm{Cu} / \mathrm{Nif}$ electrode, suggesting an improvement of the redox activity.

The recorded CV in the case of the Nif electrode shows the presence of two peaks on the cathodic branch. The first peak, located at around $0.3-0.35 \mathrm{~V}$ (vs. Ag/AgCl), presented a current plateau at low scan rates $(10 \mathrm{mV} / \mathrm{s}$, not shown here) and becomes more evident as the scan rates increased. According to the literature $[48,53],\left[\mathrm{Fe}(\mathrm{CN})_{6}\right]^{3-}$ serves as an electron acceptor favoring the oxidation of a $\mathrm{Ni}$ foam surface to $\beta-\mathrm{Ni}(\mathrm{OH})_{2}$ and further undergoes electrooxidation at high positive potentials to form $\mathrm{NiOOH}$ with no anodic peak appearance. During the reverse scan, the $\left[\mathrm{Fe}(\mathrm{CN})_{6}\right]^{4-}$ acts as an electrons donor providing the required electrons for reduction of $\mathrm{NiOOH}$, thus activating the redox reactions of 
the Nif electrode. Therefore, the cathodic peak on the recorded CV for the Nif electrode (curve 2 from Figure 5) might be assigned to $\mathrm{NiOOH}$ reduction in alkaline medium with $\mathrm{Ni}(\mathrm{OH})_{2}$ re-formation.

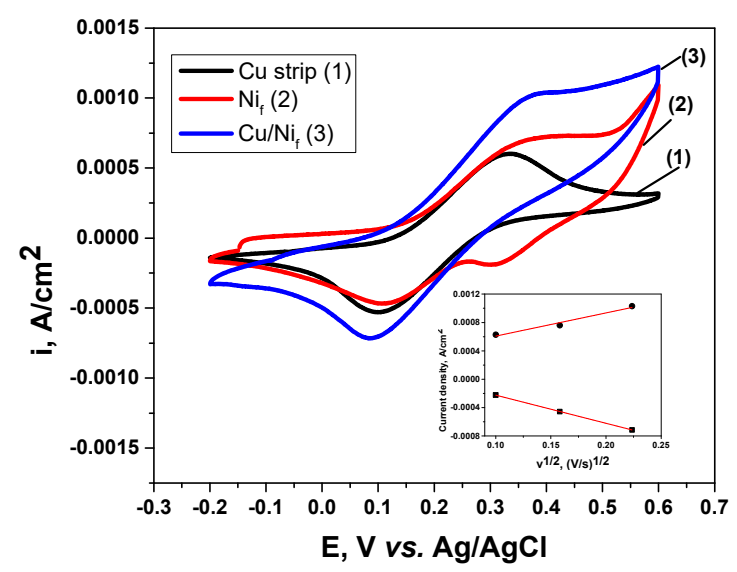

Figure 5. CVs recorded in $5 \mathrm{mM}\left[\mathrm{Fe}(\mathrm{CN})_{6}\right]^{3-/ 4-}$ in $0.1 \mathrm{M} \mathrm{NaOH}$ solution for $\mathrm{Cu}$ strip, $\mathrm{Ni}_{\mathrm{f}}$ and $\mathrm{Cu} / \mathrm{Ni}_{\mathrm{f}}$ electrodes (scan rate $=50 \mathrm{mV} \mathrm{s}^{-1}$ ). The inset shows the dependence of the anodic and cathodic peak currents vs. the square root of the scan rate for the $\mathrm{Cu} / \mathrm{Ni}_{\mathrm{f}}$ electrode.

The second cathodic peak on the recorded CV for the Nif electrode at around $0.15 \mathrm{~V}$ (vs. $\mathrm{Ag} / \mathrm{AgCl}$ ) may be attributed to the cathodic process of the ferrocyanide/ferricyanide couple, in agreement also with [48].

The anodic peak to cathodic peak potential separation, $\Delta \mathrm{Ep}$, was about $150-200 \mathrm{mV}$ for the investigated electrodes, suggesting a quasi-reversible process [52]. The values of $\Delta \mathrm{Ep}$ higher than $59 \mathrm{mV}$ (for one transferred electron) might be attributed to the electrolysis conditions (the solution conductivity induces an uncompensated IR voltage drop, which increases as the scan rate is higher).

The inset of Figure 5 illustrates an example of the dependence of the anodic and cathodic peak currents against the square root of the scan rate for the $\mathrm{Cu} / \mathrm{Nif}$ electrode. The linear relation proves that this is a diffusion-controlled process for both anodic and cathodic scans. It is worth mentioning that additional experiments presented the same linear dependence was noticed for Cu strip and Nif electrodes, too (results not shown).

The properties of the $\mathrm{Cu} / \mathrm{Ni}_{\mathrm{f}}$ electrodes were evaluated in the presence of $\mathrm{Glu}$, as the model molecule. Figure 6 presents the recorded $\mathrm{CV}$ in $0.1 \mathrm{M} \mathrm{NaOH}$ electrolyte in the absence and in the presence of $0.225 \mathrm{mM}$ Glu at a scan rate of $10 \mathrm{mV} / \mathrm{s}$.

As can be seen from Figure 5, during the anodic scan, an increase of the current was observed at $+0.55 \mathrm{~V}$ vs. $\mathrm{Ag} / \mathrm{AgCl}$ in the presence of $0.225 \mathrm{mM} \mathrm{Glu}$, assigned to the Glu oxidation. In addition, the slight increase in the capacitive current corresponds to the electrochemical oxidation of the target analyte. When the same experiment was performed in the absence of Glu, no peak was noticed.

Therefore, the potential value of $+0.55 \mathrm{~V}$ vs. $\mathrm{Ag} / \mathrm{AgCl}$ was employed for the evaluation of the analytical performance of the $\mathrm{Cu} / \mathrm{Ni}_{\mathrm{f}}$ electrode for the electrochemical detection of Glu using steady state amperometric measurements in $0.1 \mathrm{M} \mathrm{NaOH}$ solution.

As presented in Figure 7, the signal was stabilized for $400 \mathrm{~s}$ followed by standard additions of $2.5 \mathrm{mM}(12.5-25 \mu \mathrm{L})$ and $25 \mathrm{mM}$ Glu $(50 \mu \mathrm{L})$ solutions in $0.1 \mathrm{M} \mathrm{NaOH}$ every $100 \mathrm{~s}$. The signal corresponding to the electrochemical oxidation of Glu followed a stair-like augmentation trend. It is clearly visible that the signal stabilized in almost $5 \mathrm{~s}$ after the addition of the standard solution, suggesting that the presence of the porous morphology of the $\mathrm{Cu} / \mathrm{Ni}_{\mathrm{f}}$ electrode improved the electrochemical transfer rate and allowed the rapid oxidation of the analyte. 


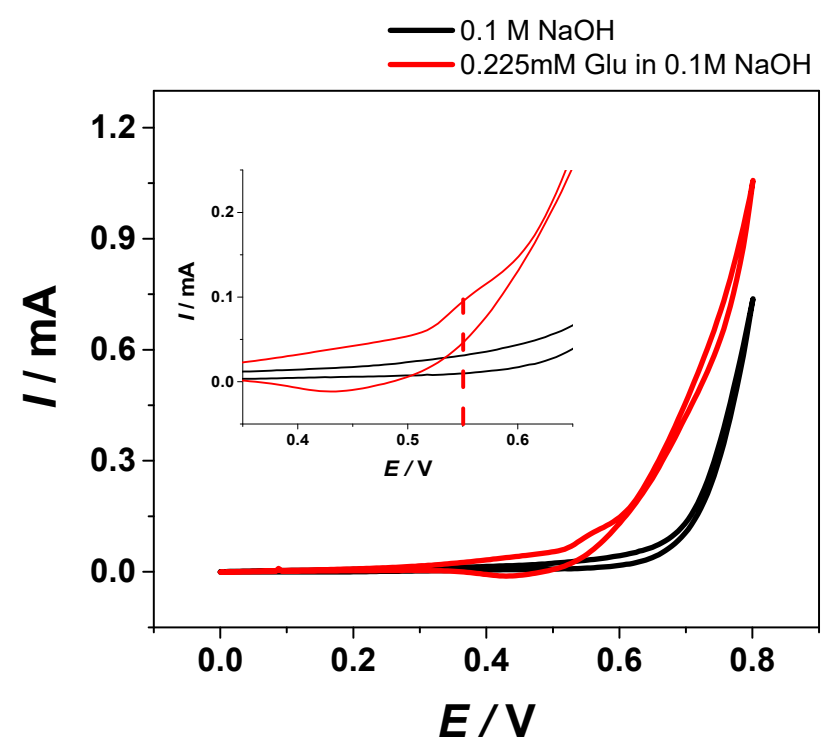

Figure 6. $\mathrm{CV}$ of the $\mathrm{Cu} / \mathrm{Ni}_{\mathrm{f}}$ working electrode in the absence (black line) and in the presence of 0.225 $\mathrm{mM}$ Glu (red line) in $0.1 \mathrm{M} \mathrm{NaOH}$ aqueous solution (scan rate: $10 \mathrm{mV} / \mathrm{s}$, working electrode surface area of $\left.25 \mathrm{~mm}^{2}\right)$.

A
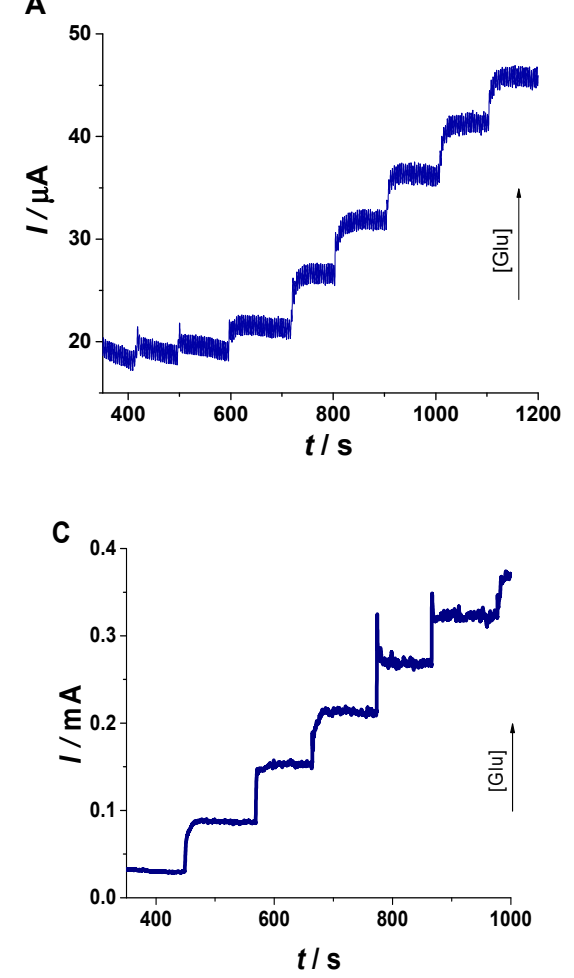

B

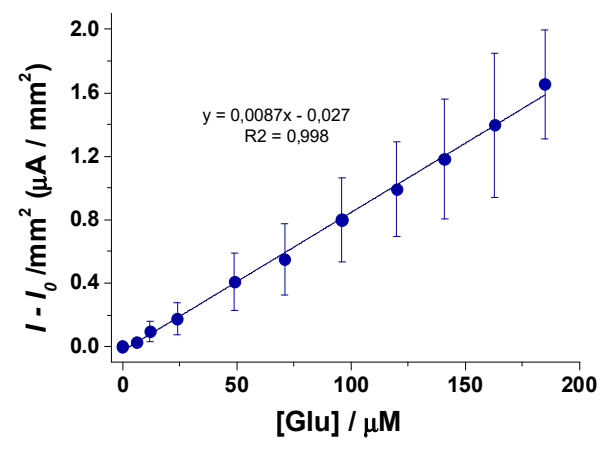

D

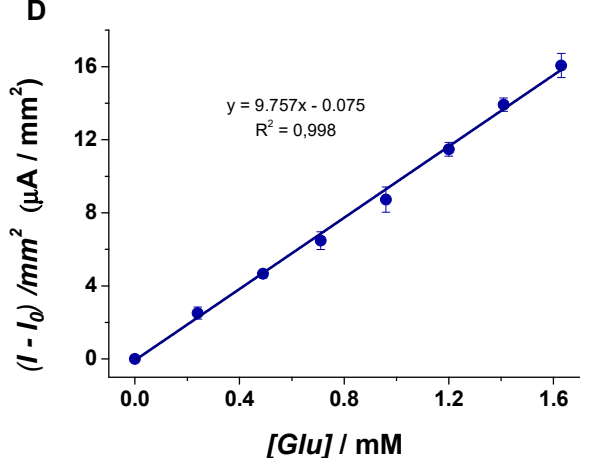

Figure 7. (A) $\mathrm{CA}$ of $\mathrm{CuNi}_{\mathrm{f}}$ electrodes in $0.1 \mathrm{M} \mathrm{NaOH}$ with standard additions of $2.5 \mathrm{mM}$ Glu every $100 \mathrm{~s}$ (4 times of $12.5 \mu \mathrm{L}$ to reach small concentration difference and then $25-50 \mu \mathrm{L}$ until the end of analysis), under continuous stirring at $500 \mathrm{rpm}$ ( $0.55 \mathrm{~V}, 0.1 \mathrm{~s}$ step potential, $1200 \mathrm{~s}$ analysis time); (B) the calibration curve in the range of $6-185 \mu \mathrm{M} \mathrm{Glu}$; (C) CA of $\mathrm{CuNi}_{\mathrm{f}}$ electrodes in $0.1 \mathrm{M} \mathrm{NaOH}$ with standard additions of $25 \mathrm{mM}$ Glu every $100 \mathrm{~s}$ of solution $(50 \mu \mathrm{L})$ under continuous stirring at $500 \mathrm{rpm}$ (0.55 V, 0.1 s step potential); (D) the calibration curve in the range of $0.24-1.63 \mathrm{mM}$ Glu.

When plotting $\mathrm{I}-\mathrm{I}_{0} / \mathrm{mm}^{2}$ against Glu concentration in the case of the experiments performed on standard solutions, a proportional increase was observed (see Figure 7A,C). Two calibration curves were obtained for the elaborated platform, as follows: 
(i) The first one in the range of $6-206 \mu \mathrm{M}$ defined by the equation $\mathrm{y}\left(\mu \mathrm{A} / \mathrm{mm}^{2}\right)=0.0087 \times[\mathrm{Glu}(\mu \mathrm{M})]$ - $0.027\left(R^{2}=0.998\right)$ has the role to demonstrate the analytical performances of the sensor, with a limit of detection (LOD) calculated as signal/noise $=3$ of $2 \mu \mathrm{M}$ and a limit of quantification (LOQ) of $6 \mu \mathrm{M}$.

(ii) The second one in the range of $0.24-1.63 \mathrm{mM}$ defined by $\mathrm{y}\left(\mu \mathrm{A} / \mathrm{mm}^{2}\right)=9.757 \times[\mathrm{Glu}(\mathrm{mM})]-0.075$ $\left(R^{2}=0.996\right)$ underlines the possibility to employ the sensor in real scenarios. The normal level of blood Glu is found to be in the 3-5.5 mM range, and in this case, the sensor could be successfully used to assess even hyperglycemic pathological levels after the dilution of the sample with an electrolyte solution (1:10 or even 1:100). Thus, the calculated concentrations will be found in the linear range and, taking into account the dilutions step, the real value of blood Glu could be determined. Further studies will be performed in order to extend the analytical performances.

A control experiment was performed on the bare $\mathrm{Cu}$ strip electrode having a similar geometrical surface, in order to evaluate the impact of the presence of the porous morphology due to the $\mathrm{Cu} / \mathrm{Ni}_{\mathrm{f}}$ substrate on the detection of Glu. The experiments were performed in the presence of $25 \mathrm{mM}$ Glu in order to be compared with the data obtained on the $\mathrm{Cu} / \mathrm{Ni}_{\mathrm{f}}$ electrode for the second linear range close to the physiological levels of Glu. According to the CA and calibration curves presented in Figure 8, it is clearly observed that the sensor based on metallic foam has a two-fold higher sensitivity than in the case of the unmodified one. Thus, the $\mathrm{Cu} / \mathrm{Ni}_{\mathrm{f}}$ configuration yielded more reliable results for Glu detection.
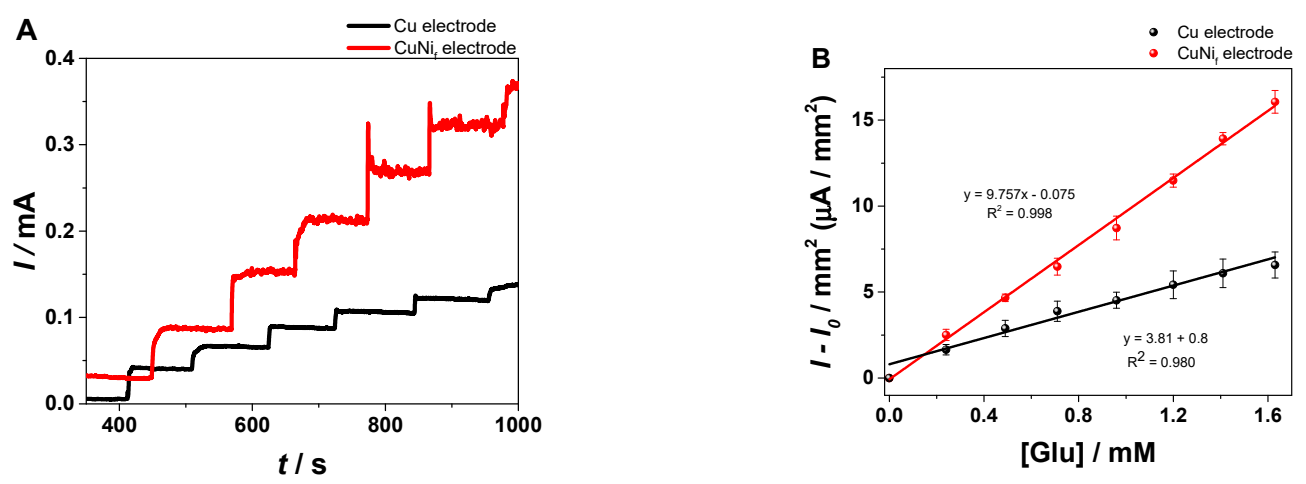

Figure 8. (A) CA on $\mathrm{Cu}$ strip electrodes (black line) and $\mathrm{Cu} / \mathrm{Ni}_{\mathrm{f}}$ on $\mathrm{Cu}$ substrate electrodes (red line) in $5 \mathrm{~mL} 0.1 \mathrm{M} \mathrm{NaOH}$ with standard additions of $25 \mathrm{mM}$ Glu every $100 \mathrm{~s}(50 \mu \mathrm{L}$ under continuous stirring at $500 \mathrm{rpm})(0.55 \mathrm{~V}, 0.1$ step potential, $1200 \mathrm{~s}$ analysis time, $500 \mathrm{rpm})$. (B) The corresponding calibration curves for the $\mathrm{Cu}$ bare electrode (black line) and $\mathrm{Cu} / \mathrm{Ni}_{\mathrm{f}}$ on $\mathrm{Cu}$ electrode (red line).

\subsection{Interferences Studies}

Selectivity is one of the most important parameters that characterizes an amperometric sensor and it shows the sensors capacity to detect the target analyte from a complex matrix. Interferences studies were carried out in the presence of common analytes found with Glu in biological fluids, such as UA, $\mathrm{P}, \mathrm{AA}$ and sugars like $\mathrm{R}$.

The selectivity of the $\mathrm{Cu} / \mathrm{Ni}_{\mathrm{f}}$ platform for Glu was firstly assessed using $\mathrm{CV}$ recorded in $0.1 \mathrm{M}$ $\mathrm{NaOH}$ solution in the presence of $150 \mu \mathrm{M}$ interfering molecule, in the absence/presence of $150 \mu \mathrm{M}$ Glu (Figure 9). 

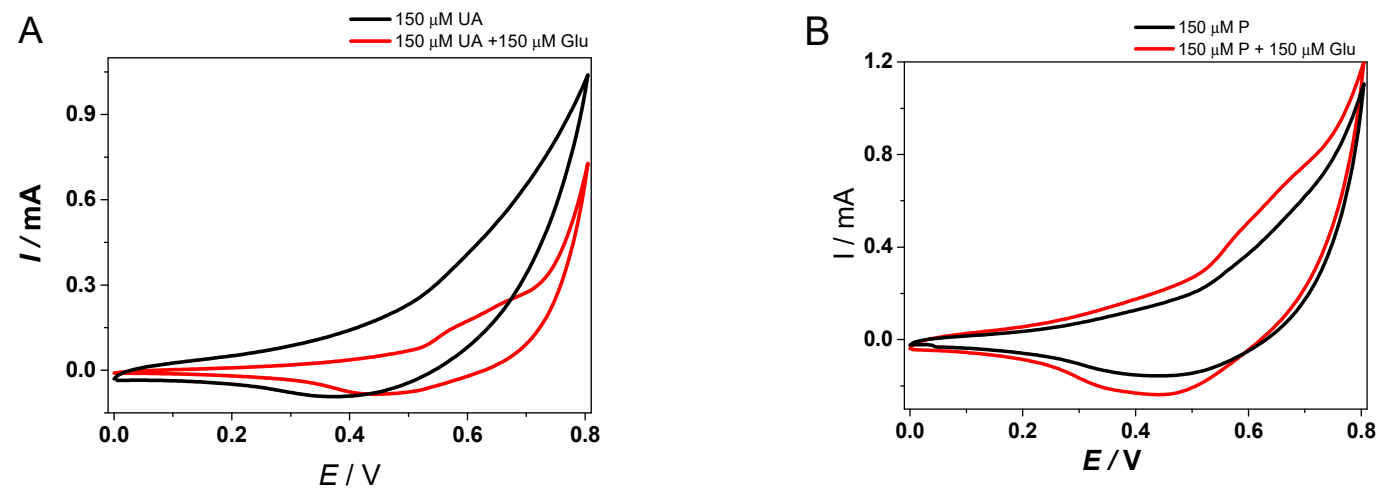

Figure 9. $\mathrm{CV}$ in $0.1 \mathrm{M} \mathrm{NaOH}$ solution in the presence of $150 \mu \mathrm{M} \mathrm{UA}(\mathbf{A})$ and $150 \mu \mathrm{M} \mathrm{P}(\mathbf{B})$ as interfering agents in the absence (black line)/presence (red line) of $150 \mu \mathrm{M}$ Glu. $(0-0.8 \mathrm{~V}$, scan rate $25 \mathrm{mV} / \mathrm{s}$, working electrode surface area of $25 \mathrm{~mm}^{2}$ ).

It can be clearly seen that on the $\mathrm{Cu} / \mathrm{Ni}_{\mathrm{f}}$ configuration the presence of both $\mathrm{UA}$ and $\mathrm{P}$ did not interfere with the anodic signal corresponding to the electrochemical oxidation of Glu.

The current responses of Glu, UA, P, AA and R were also investigated at a constant potential of $+0.55 \mathrm{~V}$ vs. $\mathrm{Ag} / \mathrm{AgCl}$, applying the same protocol as previously detailed, and the results are presented in Figure 10.

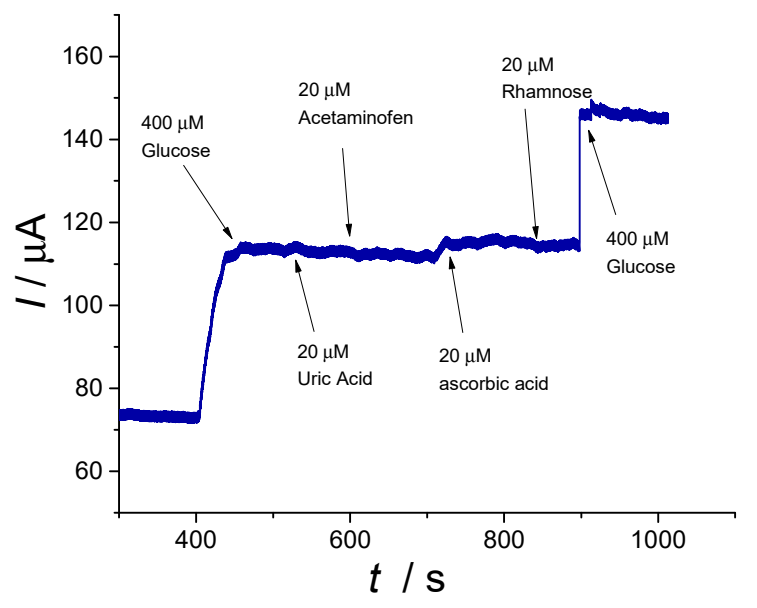

Figure 10. Amperometric responses in $0.1 \mathrm{M} \mathrm{NaOH}$ solution with standard additions every $100 \mathrm{~s}$ of 400 $\mu \mathrm{M}$ Glu, $20 \mu \mathrm{M}$ UA, P, AA, R and $400 \mu \mathrm{M}$ Glu $\left(\mathrm{E}_{\mathrm{p}}=+0.55 \mathrm{~V}, 1100 \mathrm{~s}\right)$ for the $\mathrm{Cu} / \mathrm{Ni}_{\mathrm{f}}$ electrode (working electrode area of $25 \mathrm{~mm}^{2}$ ).

After the signal stabilization, a standard addition of Glu was made corresponding to $400 \mu \mathrm{M}$ Glu concentration. Different volumes of interfering agents were added every $100 \mathrm{~s}$ (final concentrations of $20 \mu \mathrm{M}$ were achieved). Finally, after the interfering molecules, another Glu standard addition corresponding to $400 \mu \mathrm{M}$ was performed. As expected from the CVs in the presence of Glu and P, respectively UA, the studied molecules did not have any influence on the electrochemical oxidation of the model molecule. A slight increase of the anodic current was observed when AA was injected, but with a minimum influence on the Glu signal, as can be seen from Figure 9. Overall, one can appreciate the use of the $\mathrm{Cu} / \mathrm{Ni}_{\mathrm{f}}$ electrode providing a promising response in the presence of the above-mentioned compounds, thus showing potential to be considered for real case scenarios.

\subsection{Studies on Real Samples}

The amperometric sensor was tested in commercial human serum spiked with $0.1 \mathrm{MGlu}$ (Figure 11). The sample was diluted with $0.1 \mathrm{M} \mathrm{NaOH}$ (1:100 ratio) without filtration or any other pretreatment 
step. The $\mathrm{I}-\mathrm{I}_{0} / \mathrm{mm}^{2}$ was plotted against Glu concentration and a proportional increase of the signal was observed. When the results were compared with those obtained on the standard solutions no significant differences were observed, suggesting that the sensor has the potential to be applied on real samples but only after a dilution of the real samples due to the fact that the linearity domain is $0.24-1.63 \mathrm{mM}$ and it does not reach pathological hyperglycemia levels.

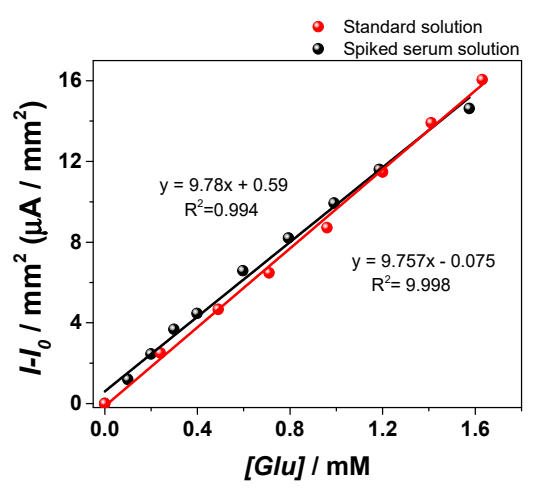

Figure 11. Calibration curve for the $\mathrm{Cu} / \mathrm{Nif}$ on $\mathrm{Cu}$ electrode in the range of $0.24-1.63 \mathrm{mM}$ Glu (red line) performed on standard solutions and on commercial human serum spiked with $0.1 \mathrm{M}$ Glu (black line) ( $0.55 \mathrm{~V}, 0.1 \mathrm{~s}$ step potential, $1200 \mathrm{~s}$ analysis time).

Table 4 presents other non-enzymatic Glu sensors involving different nanomaterials. Usually, they consist of various metallic morphologies sometimes associated with carbon-based nanomaterials.

Table 4. Cu- and Ni-based electrochemical enzymeless sensors developed for Glu detection and their analytical parameters.

\begin{tabular}{|c|c|c|c|c|c|c|}
\hline No. & Platform & $\begin{array}{l}\text { Detection } \\
\text { Method }\end{array}$ & $\begin{array}{c}\text { LOD } \\
\mu \mathrm{M}\end{array}$ & $\begin{array}{c}\text { Linearity } \\
\mu \mathrm{M}\end{array}$ & Interfering Species & Ref. \\
\hline 1. & NiNPs/ERGO & $\mathrm{CA}$ & 0.04 & $0.5-244$ & Dopamine, UA, AA & [33] \\
\hline 2. & Cu-NW-CNT-BL/GCE & $\mathrm{EIS}, \mathrm{CV}, \mathrm{CA}$ & $0.33 \times 10^{-3}$ & 10-2000 & $\begin{array}{l}\text { Sucrose, Fructose, } \\
\text { Maltose, AA, } \\
\text { Dopamine }\end{array}$ & [2] \\
\hline 3. & $\mathrm{CuO}$ nanorod & CA & 1 & $1-1250$ & $\begin{array}{c}\text { UA, AA } \\
\text { Dopamine }\end{array}$ & [21] \\
\hline 4. & $\begin{array}{c}\mathrm{Cu}-\mathrm{Cu}_{2} \mathrm{~S} \\
\text { nanocomposite/GCE }\end{array}$ & $\begin{array}{l}\mathrm{CV} \\
\mathrm{CA}\end{array}$ & 0.33 & $0.5-500$ & $\begin{array}{l}\text { Fructose, Sucrose, } \\
\text { AA, UA, Dopamine }\end{array}$ & [12] \\
\hline 5 & $\begin{array}{c}\text { CuO nanorods - } \\
\text { AuNP }\end{array}$ & LSV & 0.17 & $5-1325$ & $\begin{array}{l}\text { AA, UA, Dopamine, } \\
\text { Ureea, Sucrose }\end{array}$ & [13] \\
\hline 6. & $\mathrm{Pt} / \mathrm{Ni} @ \mathrm{rGO}$ & CA & 6.3 & $20-5000$ & AA, Phenol, Ethanol & [14] \\
\hline 7. & $\mathrm{Cu} / \mathrm{Ni}$ Foam & CA & 2 & $\begin{array}{c}6-206 \\
240-1630\end{array}$ & UA, AA, R, P & This work \\
\hline
\end{tabular}

The analytical performances of the developed sensors are similar with those obtained in the revised literature, and the linear range covers the physiological and pathological levels if the sample is priorly diluted with a compatible electrolyte.

The metallic porous electrodes, such as the one proposed in the present investigation, could be a low cost and adequate alternative to replace glucose oxidase without lacking in analytical properties. Likewise, the replacement of standard Glassy carbon electrodes with 3D Cu-based architectures could change the perspective of this approach and reduce the cost involved in the elaboration. The interference studies mentioned in our work are similar to those already reported and will have a positive input for further studies on this topic. 


\section{Conclusions}

As a result of the performed investigations, 3D electroformed copper structures have been successfully synthesized, involving $\mathrm{Ni}$ foams as promotor of a nanoporous morphology. SEM images showed the growth of porous architectures usually consisting of pores having diameters in the range of 10 to $20 \mu \mathrm{m}$ and an internal structure of the Cu deposit possessing a globular-like structure with an average diameter of about $100 \mathrm{~nm}$.

The functionalization of the porous structure by applying $\mathrm{Cu}$ additional coatings facilitated an enhanced electroanalytical response related to the non-enzymatic detection of Glu using amperometry in the presence of common interfering species.

These results confirm that 3D Cu nanostructures may successfully act as electrode material for the sensing of Glu with promising potential for application in real case scenarios.

Author Contributions: Conceptualization, L.A., M.E. and C.C; methodology, L.A, A.P., C.C. and A.C.; software L.A., A.P., G.M. and A.C.; validation, L.A., C.C. and A.C.; formal analysis, G.M. and O.L.; investigation, G.M., A.P., O.L. and A.C.; resources, L.A., M.E. and C.C; data curation, L.A., G.M., A.P. and A.C.; writing-original draft preparation, L.A., A.P., G.M. and A.C.; writing-review and editing, L.A., C.C. and A.C.; visualization, C.C. and L.A.; supervision, C.C. and L.A.; project administration, C.C. and L.A.; funding acquisition, C.C. and L.A. All authors have read and agreed to the published version of the manuscript.

Funding: This research was funded by the Romanian National Authority for Scientific Research and Innovation, CNCS/CCCDI-UEFISCDI, grant number PN-III-P1-1.2-PCCDI2017-0407/39PCCDI/2018 (INTELMAT) and UMF "Iuliu Hatieganu" Cluj-Napoca grant no. 2462/37/ 17.01.2020.

Conflicts of Interest: The authors declare no conflicts of interest.

\section{References}

1. World Health Organization Global Report on Diabetes. Available online: https://www.who.int/diabetes/ global-report/en/ (accessed on 4 May 2020).

2. Palve, Y.P.; Jha, N. A novel bilayer of copper nanowire and carbon nanotube electrode for highly sensitive enzyme free glucose detection. Mater. Chem. Phys. 2020, 240, 122086. [CrossRef]

3. Steiner, M.S.; Duerkop, A.; Wolfbeis, O.S. Optical methods for sensing glucose. Chem. Soc. Rev. 2011, 40, 4805-4839. [CrossRef] [PubMed]

4. Morris, N.A.; Cardosi, M.F.; Birch, B.J.; Turner, A.P.F. An electrochemical capillary fill device for the analysis of glucose incorporating glucose oxidase and ruthenium (III) hexamine as mediator. Electroanalysis 1992, 4, 1-9. [CrossRef]

5. Cheng, Z.; Wang, E.; Yang, X. Capacitive detection of glucose using molecularly imprinted polymers. Biosens. Bioelectron. 2001, 16, 179-185. [CrossRef]

6. Yoo, E.-H.; Lee, S.-Y. Glucose biosensors: An overview of use in clinical practice. Sensors 2010, 10, 4558-4576. [CrossRef]

7. Länge, K.; Rapp, B.E.; Rapp, M. Surface acoustic wave biosensors: A review. Anal. Bioanal. Chem. 2008, 391, 1509-1519. [CrossRef]

8. Miller, P.R.; Skoog, S.A.; Edwards, T.L.; Wheeler, D.R.; Xiao, X.; Brozik, S.M.; Polsky, R.; Narayan, R.J. Hollow Microneedle-based sensor for multiplexed transdermal electrochemical sensing. J. Vis. Exp. 2012, e4067. [CrossRef]

9. Hwang, D.W.; Lee, S.; Seo, M.; Chung, T.D. Recent advances in electrochemical non-enzymatic glucose sensors-A review. Anal. Chim. Acta 2018, 1033, 1-34. [CrossRef]

10. Cernat, A.; Le Goff, A.; Holzinger, M.; Sandulescu, R.; Cosnier, S. Micro- to nanostructured poly(pyrrole-nitrilotriacetic acid) films via nanosphere templates: Applications to 3D enzyme attachment by affinity interactions. Anal. Bioanal. Chem. 2014, 406. [CrossRef]

11. Saei, A.A.; Dolatabadi, J.E.N.; Najafi-Marandi, P.; Abhari, A.; de la Guardia, M. Electrochemical biosensors for glucose based on metal nanoparticles. Trends Anal. Chem. 2013, 42, 216-227. [CrossRef]

12. Xu, G.R.; Ge, C.; Liu, D.; Jin, L.; Li, Y.C.; Zhang, T.H.; Rahman, M.M.; Li, X.B.; Kim, W. In-situ electrochemical deposition of dendritic $\mathrm{Cu}$-Cu2S nanocomposites onto glassy carbon electrode for sensitive and non-enzymatic detection of glucose. J. Electroanal. Chem. 2019, 847, 113177. [CrossRef] 
13. Chakraborty, P.; Dhar, S.; Debnath, K.; Majumder, T.; Mondal, S.P. Non-enzymatic and non-invasive glucose detection using Au nanoparticle decorated CuO nanorods. Sens. Actuators B Chem. 2019, 283, 776-785. [CrossRef]

14. Ayranci, R.; Demirkan, B.; Sen, B.; Şavk, A.; Ak, M.; Şen, F. Use of the monodisperse Pt/Ni@rGO nanocomposite synthesized by ultrasonic hydroxide assisted reduction method in electrochemical nonenzymatic glucose detection. Mater. Sci. Eng. C 2019, 99, 951-956. [CrossRef]

15. Zhu, C.; Yang, G.; Li, H.; Du, D.; Lin, Y. Electrochemical sensors and biosensors based on nanomaterials and nanostructures. Anal. Chem. 2015, 87, 230-249. [CrossRef] [PubMed]

16. Zhang, Y.; Su, L.; Manuzzi, D.; de los Monteros, H.V.E.; Jia, W.; Huo, D.; Hou, C.; Lei, Y. Ultrasensitive and selective non-enzymatic glucose detection using copper nanowires. Biosens. Bioelectron. 2012, 31, 426-432. [CrossRef] [PubMed]

17. Mihai, G.; Roşoiu, S.; Costovici, S..; Anicăi, L.; Enăchescu, M. Synthesis of copper nanowires using aqueous and ionic liquid electrolytes for electrochemical detection. U.P.B Sci. Bull. Ser. B 2019, 81, 1-16.

18. Wang, Q.; Subramanian, P.; Li, M.; Yeap, W.S.; Haenen, K.; Coffinier, Y.; Boukherroub, R.; Szunerits, S. Non-enzymatic glucose sensing on long and short diamond nanowire electrodes. Electrochem. Commun. 2013, 34, 286-290. [CrossRef]

19. Gupta, J.; Arya, S.; Verma, S.; Singh, A.; Sharma, A.; Singh, B.; Prerna; Sharma, R. Performance of template-assisted electrodeposited Copper/Cobalt bilayered nanowires as an efficient glucose and Uric acid senor. Mater. Chem. Phys. 2019, 238, 121969. [CrossRef]

20. Çiftçi, H.; Tamer, U. Functional gold nanorod particles on conducting polymer poly(3-octylthiophene) as non-enzymatic glucose sensor. React. Funct. Polym. 2012, 72, 127-132. [CrossRef]

21. Kim, K.; Kim, S.; Lee, H.N.; Park, Y.M.; Bae, Y.S.; Kim, H.J. Electrochemically derived CuO nanorod from copper-based metal-organic framework for non-enzymatic detection of glucose. Appl. Surf. Sci. 2019, 479, 720-726. [CrossRef]

22. Weremfo, A.; Fong, S.T.C.; Khan, A.; Hibbert, D.B.; Zhao, C. Electrochemically roughened nanoporous platinum electrodes for non-enzymatic glucose sensors. Electrochim. Acta 2017, 231, 20-26. [CrossRef]

23. Lee, S.; Lee, J.; Park, S.; Boo, H.; Kim, H.C.; Chung, T.D. Disposable non-enzymatic blood glucose sensing strip based on nanoporous platinum particles. Appl. Mater. Today 2018, 10, 24-29. [CrossRef]

24. Guo, M.Q.; Hong, H.S.; Tang, X.N.; Fang, H.D.; Xu, X.H. Ultrasonic electrodeposition of platinum nanoflowers and their application in nonenzymatic glucose sensors. Electrochim. Acta 2012, 63, 1-8. [CrossRef]

25. Su, C.; Zhang, C.; Lu, G.; Ma, C. Nonenzymatic electrochemical glucose sensor based on pt nanoparticles/mesoporous carbon matrix. Electroanalysis 2010, 22, 1901-1905. [CrossRef]

26. Zhou, Y.G.; Yang, S.; Qian, Q.Y.; Xia, X.H. Gold nanoparticles integrated in a nanotube array for electrochemical detection of glucose. Electrochem. Commun. 2009, 11, 216-219. [CrossRef]

27. Cherevko, S.; Chung, C.H. Gold nanowire array electrode for non-enzymatic voltammetric and amperometric glucose detection. Sens. Actuators B Chem. 2009, 142, 216-223. [CrossRef]

28. Chang, G.; Shu, H.; Ji, K.; Oyama, M.; Liu, X.; He, Y. Gold nanoparticles directly modified glassy carbon electrode for non-enzymatic detection of glucose. Appl. Surf. Sci. 2014, 288, 524-529. [CrossRef]

29. Liu, Y.; Ding, Y.; Zhang, Y.; Lei, Y. Pt-Au nanocorals, Pt nanofibers and Au microparticles prepared by electrospinning and calcination for nonenzymatic glucose sensing in neutral and alkaline environment. Sens. Actuators B Chem. 2012, 171, 954-961. [CrossRef]

30. Niu, X.; Lan, M.; Chen, C.; Zhao, H. Nonenzymatic electrochemical glucose sensor based on novel Pt-Pd nanoflakes. Talanta 2012, 99, 1062-1067. [CrossRef]

31. Xu, C.; Liu, Y.; Su, F.; Liu, A.; Qiu, H. Nanoporous PtAg and PtCu alloys with hollow ligaments for enhanced electrocatalysis and glucose biosensing. Biosens. Bioelectron. 2011, 27, 160-166. [CrossRef] [PubMed]

32. Niu, X.; Li, X.; Pan, J.; He, Y.; Qiu, F.; Yan, Y. Recent advances in non-enzymatic electrochemical glucose sensors based on non-precious transition metal materials: Opportunities and challenges. RSC Adv. 2016, 6, 84893-84905. [CrossRef]

33. Kurt Urhan, B.; Demir, Ü.; Öznülüer Özer, T.; Öztürk Doğan, H. Electrochemical fabrication of Ni nanoparticles-decorated electrochemically reduced graphene oxide composite electrode for non-enzymatic glucose detection. Thin Solid Films 2020, 693. [CrossRef] 
34. Sim, H.; Kim, J.H.; Lee, S.K.; Song, M.J.; Yoon, D.H.; Lim, D.S.; Hong, S.I. High-sensitivity non-enzymatic glucose biosensor based on $\mathrm{Cu}(\mathrm{OH}) 2$ nanoflower electrode covered with boron-doped nanocrystalline diamond layer. Thin Solid Films 2012, 520, 7219-7223. [CrossRef]

35. Zhou, S.; Feng, X.; Shi, H.; Chen, J.; Zhang, F.; Song, W. Direct growth of vertically aligned arrays of $\mathrm{Cu}(\mathrm{OH}) 2$ nanotubes for the electrochemical sensing of glucose. Sens. Actuators B Chem. 2013, 177, 445-452. [CrossRef]

36. Zhou, X.; Nie, H.; Yao, Z.; Dong, Y.; Yang, Z.; Huang, S. Facile synthesis of nanospindle-like Cu 2O/straight multi-walled carbon nanotube hybrid nanostructures and their application in enzyme-free glucose sensing. Sens. Actuators B Chem. 2012, 168, 1-7. [CrossRef]

37. Cherevko, S.; Chung, C.H. The porous $\mathrm{CuO}$ electrode fabricated by hydrogen bubble evolution and its application to highly sensitive non-enzymatic glucose detection. Talanta 2010, 80, 1371-1377. [CrossRef]

38. Lin, K.C.; Lin, Y.C.; Chen, S.M. A highly sensitive nonenzymatic glucose sensor based on multi-walled carbon nanotubes decorated with nickel and copper nanoparticles. Electrochim. Acta 2013, 96, 164-172. [CrossRef]

39. Yi, W.; Liu, J.; Chen, H.; Gao, Y.; Li, H. Copper/nickel nanoparticle decorated carbon nanotubes for nonenzymatic glucose biosensor. J. Solid State Electrochem. 2015, 19, 1511-1521. [CrossRef]

40. Guo, M.M.; Wang, P.S.; Zhou, C.H.; Xia, Y.; Huang, W.; Li, Z. An ultrasensitive non-enzymatic amperometric glucose sensor based on a $\mathrm{Cu}$-coated nanoporous gold film involving co-mediating. Sens. Actuators B Chem. 2014, 203, 388-395. [CrossRef]

41. Park, S.; Kim, H.C.; Chung, T.D. Electrochemical analysis based on nanoporous structures. Analyst 2012, 137, 3891-3903. [CrossRef] [PubMed]

42. Huang, J.F. Facile preparation of an ultrathin nickel film coated nanoporous gold electrode with the unique catalytic activity to oxidation of glucose. Chem. Commun. 2009, 1270-1272. [CrossRef] [PubMed]

43. Liu, W.; Wu, X.; Li, X. Gold nanorods on three-dimensional nickel foam: A non-enzymatic glucose sensor with enhanced electro-catalytic performance. RSC Adv. 2017, 7, 36744-36749. [CrossRef]

44. Eugénio, S.; Silva, T.M.; Carmezim, M.J.; Duarte, R.G.; Montemor, M.F. Electrodeposition and characterization of nickel-copper metallic foams for application as electrodes for supercapacitors. J. Appl. Electrochem. 2013, 44, 455-465. [CrossRef]

45. Golgovici, F.; Pumnea, A.; Petica, A.; Manea, A.C.; Brincoveanu, O.; Enachescu, M.; Anicai, L. Ni-Mo alloy nanostructures as cathodic materials for hydrogen evolution reaction during seawater electrolysis. Chem. Pap. 2018, 72, 1889-1903. [CrossRef]

46. Marozzi, C.A.; Chialvo, A.C. Development of electrode morphologies of interest in electrocatalysis. Part 1 : Electrodeposited porous nickel electrodes. Electrochim. Acta 2000, 45, 2111-2120. [CrossRef]

47. Saitou, M. Characterization of electrodeposited Ni and Ni-Mo thin films by X-ray diffraction. Int. J. Electrochem. Sci. 2014, 9, 6033-6042.

48. Gao, Z.; Chen, L.; Chang, J.; Wang, Z.; Wu, D.; Xu, F.; Jiang, K. Bare Ni foam electrode-ferricyanides redox electrolyte system with high capacitive performance. Int. J. Hydrogen Energy 2019, 44, 10554-10560. [CrossRef]

49. González-Buch, C.; Herraiz-Cardona, I.; Ortega, E.; García-Antón, J.; Pérez-Herranz, V. Study of the catalytic activity of 3D macroporous $\mathrm{Ni}$ and NiMo cathodes for hydrogen production by alkaline water electrolysis. J. Appl. Electrochem. 2016, 46, 791-803. [CrossRef]

50. Wang, M.; Wang, Z.; Yu, X.; Guo, Z. Facile one-step electrodeposition preparation of porous NiMo film as electrocatalyst for hydrogen evolution reaction. Int. J. Hydrogen Energy 2015, 40, 2173-2181. [CrossRef]

51. Marro, J.B.; Okoro, C.A.; Obeng, Y.S.; Richardson, K.C. The impact of organic additives on copper trench microstructure. J. Electrochem. Soc. 2017, 164, D543-D550. [CrossRef]

52. Scialdone, O.; Guarisco, C.; Grispo, S.; Angelo, A.D.; Galia, A. Investigation of electrode material-Redox couple systems for reverse electrodialysis processes. Part I: Iron redox couples. J. Electroanal. Chem. 2012, 681, 66-75. [CrossRef]

53. Yang, F.; Cheng, K.; Xue, X.; Yin, J.; Wang, G.; Cao, D. Three-dimensional porous Ni film electrodeposited on $\mathrm{Ni}$ foam: High performance and low-cost catalytic electrode for $\mathrm{H} 2 \mathrm{O} 2$ electrooxidation in $\mathrm{KOH}$ solution. Electrochim. Acta 2013, 107, 194-199. [CrossRef]

(C) 2020 by the authors. Licensee MDPI, Basel, Switzerland. This article is an open access article distributed under the terms and conditions of the Creative Commons Attribution (CC BY) license (http://creativecommons.org/licenses/by/4.0/). 